\title{
An Evaluation on Risk and Return of Mutual Funds in India
}

\author{
P BHUVANESWARI \\ Guest Lecturer, PG \& Research Department of Commerce, \\ Bharathidasan University College for Women, \\ Orathanadu, Thanjavur (DT), Tamil Nadu, India \\ bhuvana_phd@rediffmail.com \\ W R P K FERNANDO \\ Senior Lecturer, Department of Business Management, \\ Rajarata University of Sri Lanka, Mhintale, Sri Lanka. \\ ranjith765@yahoo.com
}

\begin{abstract}
The Indian capital market has witnessed unprecedented developments and innovations particularly during the decades of 1980s and 1990s. The review studies have analyzed different types of mutual funds by using various measures. Hence, the present study analyzed the risk and return of mutual funds performance of top performing funds for the last three years (2008-2010). The study concluded that beta values of top six schemes were significantly related to their market index values. The sample of schemes namely Reliance Banking Fund-Growth PlanGrowth Option and UTI Transportation and Logistics Fund - Growth are significantly related to their market value in 2010 only. All sample schemes except Reliance Banking Fund-Growth Plan-Growth Option earned negative returns in the year 2008. Results of the study indicate that the all sample schemes earned positive return in the year 2010.

Key words: Indian Mutual Funds, Net Asset Value, Risk and Return, Systematic Risk, Standard Deviation.

\section{Introduction}

The Indian capital market has witnessed unprecedented developments and innovations particularly during the decades of 1980s and 1990s. These innovations, inter-alia, relate to new financial instruments, new financial institutions such as mutual funds, and a variety of financial services like merchant banking credit rating, factoring etc. In the changed environment the mutual funds are playing a vital role in financial intermediation development of capital markets
\end{abstract}


and the growth of the corporate sector. Conceptually, a mutual fund is a single large professionally managed investment organisation that combines the money of many individual investors having similar investment objectives. It invests this money in a wide variety of securities and individual investors share its income and expenses, its profits and losses, its capital appreciation and growth in proportion to their shareholdings.

Mutual fund institutions are dynamic financial institutions, which play a crucial role in an economy by mobilizing savings and investing them in the capital market. Once the objectives of investment and the associated constraints have been identified, the fund managers have to select an efficient portfolio. The fund managers must also consider the appropriate risk and return of mutual funds. The present study is aimed to analyse the performance of mutual funds during the period of 2008 to 2010 . It is also proposed to examine the top performing mutual funds during the period. Market indices were selected to analyse how the index influences the returns of the mutual funds.

\section{Review of Literature}

Verma (2007) investigated the concept of Investment Style Analysis of Mutual Funds. The author conducted a survey among various financial advisors and fund managers from various Asset Management Companies and found that majority of the Mutual Funds managers adopt the security specific investment style and prefer the Bottom-Up Approach while selecting stocks. Greene, Hodges and Ranowski (2007) examined open ended Mutual Funds for the period of 2000 to 2003. The study analyzed the short term trading of fund shares, as manifested in daily fund flows and found that the redemption fee was an effective tool in controlling the volatility of fund managers. The study on analyzing the financial reports with special focus on earning of Mutual Funds by Bodhanwala (2006) empirically evaluated the portfolio formation of fund managers. Further, Begam (2006) analyzed the private sector Mutual Funds gaining prominence in India and the study concluded that the private sector has achieved emergence and rapid growth of Mutual Funds in India. Furthermore, Fama and French (2006); Busse and Irvine (2006) and Chander (2006) have investigated gaining prominence of Mutual Funds in India. 
Jiang, Yao and Yu (2007), implemented new measures of market timing based on mutual fund holdings and concluded that actively managed U.S. domestic equity funds had positive timing ability uring their study period. Deb, Banerjee, and Chakrabarti (2007) examined the market timing and stock selection ability of the Indian Mutual Funds managers with a sample of 96 Indian equity Mutual Funds schemes. Results of the study indicated that the Indian mutual fund managers had a lack of market timing ability and presence of stock selection ability in both models during the study period. Bodla and Bishnoi (2008), attempted to find out the recent trends in mutual fund industry in India and explained that both open-end and close-end schemes registered excellent growth in fund mobilization. The study found that UTI's share in total assets under management had came down to 11.8 percent in 2006 from 82.5 percent in 1998. As a whole, Mutual Funds were adding a lot to the India Shining Story by ensuring a significant growth.

The review of literature revealed that the performance of mutual funds has been analyzed by using various measures. Hence an attempt has been made in the present study to analyze the risk and return of mutual funds performance of top performing funds for the last three years (2008-2010).

\section{Research Design}

\section{Statement of the Problem}

The mutual funds industry is one of the fast growing sectors in India since the initiation of economic reforms in 1991. However, growth of mutual funds have posed difficulties to investors in making a selection of suitable schemes as presently there are more than 600 schemes as at December 2008. It is evident that even a single wrong decision of fund manager may put the investors in financial crisis, sometimes leading to their bankruptcy. Therefore, a proper performance evaluation measure is required as it will remove such confusions and help the small investors in selecting suitable mutual fund schemes for investment. 


\section{Objectives of the Study}

The study is undertaken with the following objectives,

1. To evaluate the performance of sample equity mutual funds schemes based on risk and return relationship,

2. To compare the sample mutual fund returns with their respective market returns,

\section{Methodology of the Study}

\section{Sample selection}

The present study is an attempt to analyze the performance of top ten mutual funds in India during the period of 1st January 2008 to 31 st December 2010. The details is given below the Table- 1

\section{Table 1 : List of Sample Mutual Fund Schemes during the Year 2008 to 2010}

\begin{tabular}{|c|l|}
\hline S.NO & LIST OF MUTUAL FUNDS \\
\hline 1 & Franklin Pharma Fund - Growth \\
2 & Reliance Pharma Fund - Growth \\
3 & UTI Pharma and Healthcare Fund - Growth \\
4 & Franklin Infotech Fund - Growth \\
5 & Franklin FMCG Fund - Growth \\
6 & ICICI Prudential Discovery Fund - IP- Growth \\
7 & Reliance Banking Fund - Growth \\
8 & ICICI Prudential Discovery Fund - Growth \\
9 & UTI Transportation and Logistics Fund - Growth \\
10 & Birla Sun Life Dividend Yield Plus - Growth \\
\hline
\end{tabular}

Source: Mutualfundsindia.com

\section{Source of Data}

The present study mainly depends on secondary data. The secondary data regarding top ten mutual funds schemes were collected and used for this study. For evaluating the performance of sample mutual funds, Net Asset Value (NAV) was used. The required daily NAV for sample mutual funds was obtained from the mutual funds website namely Association of Mutual Funds in India (AMFI). The value of benchmark portfolio S\&PCNX NIFTY was collected from NSE website. The other relevant information was obtained from books, journals, magazines, and various websites. 


\section{Tools used for Analysis}

The study analyzed the performance of mutual funds during the study period. Hence the following tools were used to examine the performance of mutual funds,

\section{Daily NAV Returns}

The daily average NAV returns of sample funds during the period was calculated by using the following formula,

$$
R p_{t}=\left[\frac{\mathrm{NAV}_{\mathrm{t}}-\mathrm{NAV}_{\mathrm{t}-1}}{\mathrm{NAV}_{\mathrm{t}-1}} * 100\right]
$$

Where,

$$
\begin{aligned}
R_{p t} & =\text { Portfolio return in period of } t \\
\text { NAV }_{t} & =\text { Net Asset Value in period of } t \\
\text { NAV }_{t-1} & =\text { Net Asset Value in period of } t-1
\end{aligned}
$$

\section{Daily Market Returns}

The returns on market index was calculated by using the following equation,

$$
R m_{t}=\left[\frac{\mathrm{R}_{\mathrm{t}}-\mathrm{R}_{\mathrm{t}-1}}{\mathrm{R}_{\mathrm{t}-1}} * 100\right]
$$

Where,

$$
\begin{aligned}
R_{m t} & =\text { Market index return in period of } t \\
R_{t} & =\text { Net Asset Value in period of } t \\
R_{t-1} & =\text { Net Asset Value in period of } t-1
\end{aligned}
$$

\section{Risk (Systematic)}

The reward to beta measures the excess returns per unit of market (systematic) risk. Risk (beta) for sample mutual fund schemes have been estimated by using the following equation, 
Where,

$$
b=\frac{\sum(x-\bar{x})(y-\bar{y})}{\sum(x-\bar{x})^{2}}
$$

$$
\begin{aligned}
& x=\text { returns of benchmark } \\
& y=\text { return of portfolio } \\
& b=\text { risk of the mutual funds }
\end{aligned}
$$

\section{Risk (Total)}

The excess returns per unit of total risk were measured by standard deviation. Thus, the total risk of sample mutual fund schemes have been estimated by using the following equation,

$$
\begin{aligned}
& \text { Standard deviation }=\sqrt{\frac{\sum(x-\bar{x})^{2}}{(n-1)}} \\
& \mathrm{X}=\text { returns of benchmark } \\
& \mathrm{n}=\text { no of returns }
\end{aligned}
$$

\section{T-test}

This t-test form does not assume that the variances of both populations are equal. Among the results that are generated by this tool is pooled variance, an accumulated measure of the spread of data about the mean, which is derived from the following formula.

$$
\begin{aligned}
& S^{2}=\frac{n_{1} S_{1}^{2}+n_{2} S_{2}^{2}}{n_{1}+n_{2}-2} \\
& \mathrm{n}=\text { no of returns. } \\
& \mathrm{s}=\text { spread of data about the mean }
\end{aligned}
$$




\section{Empirical Results}

The performance of Mutual Funds is measured in terms of returns per unit of risk. The sample Mutual Funds are selected on the basis of top performance during the study period of 2008 to 2010 . Moreover the study analyzed the performance of mutual funds by using risk (beta), standard deviation and return of schemes.

Table 2: Risk and Returns of Franklin Pharma Fund - Growth Scheme during the Study Period (2008 to 2010)

\begin{tabular}{|c|l|c|c|c|c|}
\hline \multicolumn{7}{|c|}{ Franklin Pharma Fund - Growth } \\
\hline Year & Risk(beta) & Return & Stdev & † Stat $(\beta)$ & P-value \\
2008 & 0.373447 & -0.0012 & 0.014631 & 15.92833 & $1.49 \mathrm{E}-39$ \\
2009 & 0.164597 & 0.003181 & 0.01108 & 5.320131 & $2.39 \mathrm{E}-07$ \\
2010 & 0.078651 & 0.001276 & 0.010279 & 1.929895 & 0.054765 \\
\hline
\end{tabular}

Source: AMFI\&NSE

The mutual fund mean return, risk (beta), standard deviation, t-statistic $(\beta)$ and p-value of Franklin Pharma Fund - Growth scheme from 2008 to 2010 are

$\alpha$ given in Table 2. It is to be noted that the return value $(-0.0012)$ in the year 2008 is negative. However, the other two years gives positive returns. It is clearly seen from the Table that the value of systematic risk (beta) 0.373447 ) and total risk (standard deviation) $(0.014631$ ) in the year 2008 is higher than other two years. The t-statistics value of systematic risk indicates that the year 2008 and 2009 are significantly related to the market value at $5 \%$ level.

Table 3 : Risk and Returns of Reliance Pharma Fund-Growth Plan-Growth Scheme during the Study Period (2008 to 2010)

\begin{tabular}{|c|c|c|c|c|c|}
\hline \multicolumn{7}{|c|}{ Reliance Pharma Fund-Growth Plan-Growth } \\
\hline Year & Risk(beta) & Return & Stdev & † Stat $(\beta)$ & P-value \\
\hline 2008 & 0.27641 & -0.00165 & 0.020232 & 6.525818 & $3.98 \mathrm{E}-10$ \\
2009 & 0.181398 & 0.003374 & 0.015427 & 4.121618 & $5.21 \mathrm{E}-05$ \\
2010 & 0.115706 & 0.001129 & 0.007545 & 2.503325 & 0.012955 \\
\hline
\end{tabular}

Source: AMFI\&NSE 
According to the Table 3, the mutual fund mean return, risk (beta), standard deviation, t-statistic $(\beta)$ and $p$-value of Reliance Pharma Fund-Growth PlanGrowth scheme from 2008 to 2010 are given. The table explained that the return value $(-0.00165)$ in the year 2006 is negative. However the other two years gives positive returns. It is highlighted the value of systematic risk (beta) (0.27641) and total risk (standard deviation) (0.020232) in the year 2008 is higher than other two years. The t-statistics value of systematic risk indicates that all three years are significantly related to the market value at $5 \%$ level.

Table 4 : Risk and Returns of UTI Pharma \& Healthcare Fund-Growth Option Scheme during the Study Period (2008 to 2010)

\begin{tabular}{|c|l|c|c|c|c|}
\hline \multicolumn{7}{|c|}{ UTI Pharma \& Healthcare Fund-Growth Option } \\
\hline Year & Risk(beta) & Return & Stdev & † Stat $(\beta)$ & P-value \\
\hline 2008 & 0.443317 & -0.00118 & 0.016288 & 18.52237 & $3.66 E-48$ \\
2009 & 0.073296 & 0.002192 & 0.010709 & 2.343988 & 0.019909 \\
2010 & 0.148931 & 0.001299 & 0.007555 & 3.245063 & 0.001338 \\
\hline
\end{tabular}

Source: AMFI\&NSE

The mutual fund mean return, risk (beta), standard deviation, t-statistic $(\beta)$ and p-value of UTI Pharma \& Healthcare Fund-Growth Option scheme from 2008 to 2010 are displayed in Table 4. According to the table the values of return $(-0.00118)$ is negative in the year 2008. However the other two years gives positive returns. It is revealed that the value of systematic risk (beta) $(0.443317)$ and total risk (standard deviation) (0.016288) in the year 2008 is higher than other two years. The t-statistics value of systematic risk indicates that all three years are significantly related to the market value at $5 \%$ level.

Table 5 : Risk and Returns of Franklin Infotech Fund-Growth Scheme during the Study Period (2008 to 2010)

\begin{tabular}{|c|c|c|c|c|c|}
\hline \multicolumn{7}{|c|}{ Franklin Infotech Fund-Growth } \\
\hline Year & Risk(beta) & Return & Stdev & † Stat $(\beta)$ & P-value \\
\hline 2008 & 0.363076 & -0.00244 & 0.027251 & 6.262105 & $1.72 \mathrm{E}-09$ \\
2009 & 0.266157 & 0.003782 & 0.019376 & 4.877399 & $1.97 \mathrm{E}-06$ \\
2010 & 0.539357 & 0.001199 & 0.011828 & 8.339272 & $5.28 \mathrm{E}-15$ \\
\hline
\end{tabular}

Source: AMFI\&NSE 
Table 5 shows that mutual fund mean return, risk (beta), standard deviation, $t-$ statistic $(\beta)$ and $p$-value of Franklin Infotech Fund-Growth scheme from 2008 to 2010 . It is to be noted that the values of return $(-0.00244)$ is negative in the year 2008. However the other two years generates positive returns. It is explained from the Table that the value of systematic risk (beta) $(0.539357$ ) in the year 2010 and total risk (standard deviation) (0.027251) in the year 2008 is higher. The t-statistics value of systematic risk indicates that all three years are significantly related to the market value at $5 \%$ level.

Table 6: Risk and Returns of Franklin FMCG Fund - Growth Scheme during the Study Period (2008 to 2010)

\begin{tabular}{|c|c|c|c|c|c|}
\hline \multicolumn{7}{|c|}{ Franklin FMCG Fund - Growth } \\
\hline Year & Risk(beta) & Return & Stdev & † Stat $(\beta)$ & P-value \\
\hline 2008 & 0.386755 & -0.0012 & 0.014624 & 17.13575 & $1.22 \mathrm{E}-43$ \\
2009 & 0.13129 & 0.001983 & 0.009592 & 4.858331 & $2.15 \mathrm{E}-06$ \\
2010 & 0.365673 & 0.001224 & 0.006947 & 10.12011 & $2.44 \mathrm{E}-20$ \\
\hline
\end{tabular}

Source: AMFI\&NSE

The mutual fund mean return, risk (beta), standard deviation, t-statistic $(\beta)$ and p-value of Franklin FMCG Fund - Growth scheme from 2008 to 2010 are given in Table 6. It is to be showed that the values of return $(-0.0012)$ is negative in the year 2008. However the other two years generates positive returns. According to the Table, the value of systematic risk (beta) $(0.386755)$ and total risk (standard deviation) $(0.014624$ ) in the year 2008 is higher than other two years. The t-statistics value of systematic risk indicates that all three years are significantly related to the market value at $5 \%$ level.

Table 7 : Risk and Returns of ICICI Prudential Discovery Fund - Institutional Option - I Growth Scheme during the Study Period (2008 to 2010)

\begin{tabular}{|c|c|c|c|c|c|}
\hline \multicolumn{6}{|c|}{ ICICI Prudential Discovery Fund - Institutional Option - I - Growth } \\
\hline Year & Risk(beta) & Return & Stdev & † Stat $(\beta)$ & P-value \\
\hline 2008 & 0.647256 & -0.00305 & 0.023013 & 19.9302 & $5.89 \mathrm{E}-53$ \\
2009 & 0.52755 & 0.003638 & 0.015336 & 17.84208 & $1.18 \mathrm{E}-45$ \\
2010 & 0.574808 & 0.000991 & 0.008444 & 15.43416 & $5.3 \mathrm{E}-38$ \\
\hline
\end{tabular}

Source: AMFI\&NSE 
The mutual fund mean return, risk (beta), standard deviation, t-statistic $(\beta)$ and p-value of $\mathrm{IClCl}$ Prudential Discovery Fund - Institutional Option - I - Growth scheme from 2008 to 2010 are explained in Table 7. It is to be noted that the values of return $(-0.00305)$ is negative in the year 2008 . However the other two years generates positive returns. It is clearly seen from the Table that the value of systematic risk (beta) $(0.647256)$ and total risk (standard deviation) (0.023013) in the year 2008 is higher than other two years. The t-statistics value of systematic risk indicates that all three years are significantly related to the market value at $5 \%$ level.

Table 8 : Risk and Returns of Reliance Banking Fund-Growth Plan-Growth Option Scheme during the Study Period (2008 to 2010)

\begin{tabular}{|c|c|c|c|c|c|}
\hline \multicolumn{7}{|c|}{ Reliance Banking Fund-Growth Plan-Growth Option } \\
\hline Year & Risk(beta) & Return & Stdev & t Stat $(\beta)$ & P-value \\
\hline 2008 & -0.08002 & 0.000228 & 0.035808 & -0.97632 & 0.329883 \\
2009 & -0.03444 & 0.002957 & 0.017484 & -0.66758 & 0.505051 \\
2010 & 0.866665 & 0.000251 & 0.022529 & 6.76593 & $9.54 \mathrm{E}-11$ \\
\hline
\end{tabular}

Source: AMFI\&NSE

Table 8, provides the mutual fund mean return, risk (beta), standard deviation, t-statistic $(\beta)$ and $p$-value of Reliance Banking Fund-Growth Plan-Growth Option scheme from 2008 to 2010 . It is to be noted that the values of return on all three years are positive. It is revealed from the Table that the value of systematic risk (beta) of year 2008 and 2009 are negative. It indicates that the movements of market and the mutual fund scheme are behaving in a different way. However total risk (standard deviation) (0.035808) in the year 2008 is higher than other two years. The t-statistics value of systematic risk indicates that only the year 2010 is significantly related to the market value at $5 \%$ level. 
Table 9 :Risk and Returns of ICICI Prudential Discovery Fund-Growth Option Scheme during the Study Period (2008 to 2010)

\begin{tabular}{|c|c|c|c|c|c|}
\hline \multicolumn{7}{|c|}{ ICICI Prudential Discovery Fund-Growth Option } \\
\hline Year & Risk(beta) & Return & Stdev & † Stat $(\beta)$ & P-value \\
\hline 2008 & 0.958121 & -0.00311 & 0.023027 & 19.85578 & $1.04 \mathrm{E}-52$ \\
2009 & 0.81538 & 0.003567 & 0.015219 & 10.52516 & $1.67 \mathrm{E}-21$ \\
2010 & 0.196768 & 0.000946 & 0.008397 & 2.554229 & 0.011246 \\
\hline
\end{tabular}

Source: AMFI\&NSE

The mutual fund mean return, risk (beta), standard deviation, t-statistic $(\beta)$ and p-value of $\mathrm{IClCl}$ Prudential Discovery Fund-Growth Option scheme from 2008 to 2010 are given in Table 9. According to the table, the values of return (0.00311 ) is negative in the year 2008. However the other two years generates positive returns. It is clearly seen from the Table that the value of systematic risk (beta) (0.958121) and total risk (standard deviation) (0.023027) in the year 2008 is higher than other two years. The t-statistics value of systematic risk indicates that all three years are significantly related to the market value at $5 \%$ level.

Table 10 : Risk and Returns of UTI Transportation and Logistics Fund - Growth Scheme during the Study Period (2008 to 2010)

\begin{tabular}{|c|c|c|c|c|c|}
\hline \multicolumn{7}{|c|}{ UTI Transportation and Logistics Fund - Growth } \\
\hline Year & Risk(beta) & Return & Stdev & † Stat $(\beta)$ & P-value \\
\hline 2008 & 0.450355 & -0.0008 & 0.010639 & 1.5841 & 0.114499 \\
2009 & -0.02383 & -0.00334 & 0.015442 & -0.50256 & 0.61574 \\
2010 & 0.059647 & 0.002979 & 0.016714 & 7.600403 & $6.19 \mathrm{E}-13$ \\
\hline
\end{tabular}

Source: AMFI\&NSE

The mutual fund mean return, risk (beta), standard deviation, t-statistic $(\beta)$ and p-value of UTI Transportation and Logistics Fund - Growth scheme from 2008 to 2010 are presented in Table 10. It is to be displayed that the values of return are negative in the year 2008 and 2009. However in the year 2010 presents positive returns. It is clearly seen from the Table that the value of systematic risk (beta) $(-0.02383$ ) is negative in the year 2009. Nevertheless the other two years are positive beta values. It is understood that the schemes' 
movement are directly related to market index. The total risk (standard deviation) (0.016714) in the year 2010 is higher than other two years. The tstatistics value of systematic risk indicates that only the year 2010 is significantly related to the market value at $5 \%$ level.

Table 11: Risk and Returns of Birla Sun Life Dividend Yield Plus-Plan B (Growth) Scheme during the Study Period (2008 to 2010)

\begin{tabular}{|c|c|c|c|c|c|}
\hline \multicolumn{7}{|c|}{ Birla Sun Life Dividend Yield Plus-Plan B (Growth) } \\
\hline Year & Risk(beta) & Return & Stdev & † Stat $(\beta)$ & P-value \\
\hline 2008 & 0.287239 & -0.00218 & 0.019601 & 6.999801 & $2.53 E-11$ \\
2009 & 0.130063 & -0.00086 & 0.053551 & 0.823299 & 0.411165 \\
2010 & -2.56887 & 0.019092 & 0.290153 & -1.43337 & 0.153023 \\
\hline
\end{tabular}

Source: AMFI\&NSE

The mutual fund mean return, risk (beta), standard deviation, t-statistic $(\beta)$ and p-value of Birla Sun Life Dividend Yield Plus-Plan B (Growth) scheme from 2008 to 2010 are given in Table 11 . It is to be noted that the values of return are negative in the year 2008 and 2009. However the year 2010 gives positive returns. It is clearly seen from the table that the value of systematic risk (beta) (-2.56887) is negative in the year 2010. It indicates that the market index movements and the mutual fund scheme movements are contrary. Moreover total risk (standard deviation) (0.290153) in the year 2010 is higher than other two years. The t-statistics value of systematic risk indicates that only year 2008 is significantly related to the market value at $5 \%$ level.

\section{Conclusion}

The present study is concluded that beta values of first top six sample schemes were significantly related to their market index values. However the sample schemes namely Reliance Banking Fund-Growth Plan-Growth Option and UTI Transportation and Logistics Fund - Growth are significantly related to their market value in 2010 only. All sample schemes except Reliance Banking FundGrowth Plan-Growth Option earned negative returns in the year 2008. Moreover the results of above analysis indicate that the all sample schemes earned positive return in the year 2010. 
Indian Mutual Funds have emerged as strong financial intermediaries and they play a significant role in bringing stability into the financial system and efficiency in resource allocation. The present article encompasses an analysis of the performance of selected sample Mutual Fund Schemes. The results of this study found that the performances of majority of the sample Equity Schemes were significantly related to their market movements during the study period. However some of the schemes are not significantly related to market movements.

\section{Reference}

Beegam R (2006). Private Sector Mutual Funds Gaining Prominence in India. Southern Economist. Vol.44(18): 23-25.

Bodla S.B, Bishnoi S. (2008). Emerging Trends of Mutual Funds in India: A Study across Category and Type of Schemes. JIMS 8M.Jan-Mar:15-27.

Bobhanwala R.J (2006). An Empirical Study on Analyzing How Fund Managers in India Analyze Financial Reports with Special Focus on Quality of Reported Earning. Applied Finance. Vol.12(9): 5-38.

Busse J.A, and Irvine P.J (2006). Bayesian Alphas and Mutual Fund Persistenace. J. Finance. Vol. 61(5): 2251-2288.

Chander R (2006). Investment Managers' Market Timing Abilities: Empirical Evidence from the Indian Capital Market. IIMB Management Review. Vol.18(4):315-326.

Deb S.J, Banerjee A, Chakrabarti B.B. (2007). Market Timing and Stock Selection Ability of Mutual Funds in India: An Empirical Investigation. Vikalpa. Vol.32(2):39-51.

Fama,E .F and French, K.R (2006). The Value Premium and the CAPM. J. Finance. Vol. 61(5): 2163-2185.

Greene J.T., Hodges W.C, and Rakowski, R.A (2007): Daily Mutual Fund Flows and Redemption Policies. J. Banking and Finance, Vol.31: 3822-3842.

Jiang G.J., Yao T. and Yu, T (2007). Do Mutual Funds Time the Market? Evidence from Portfolio Holdings. J. Financial Economics Vol.86(3): 724- 758.

Verma, M (2007). Style Analysis of Mutual Funds. Portfolio Organizer. Vol.8(5): $34-46$. 